\title{
Abundance and Food Preferences of Amphipods (Crustacea: Amphipoda) in the Eastern Gulf of Finland, Baltic Sea
}

\author{
Nadezhda A. Berezina* and Alexey A. Maximov \\ Zoological Institute of the RAS \\ 1 Universitetskaya Emb., Saint-Petersburg, 199034, Russia
}

Received 20.06.2016, received in revised form 14.07.2016, accepted 09.10.2016

This paper focuses on the group of the estuarine Baltic amphipods describing abundance and biomass of their representatives in the shallow-and deep water communities of the eastern part of the Gulf of Finland and assessing their food habits. Actuality of this study is determined by an increase in the number of species and abundance of amphipods in the ecosystem of the Gulf of Finland in recent years, mainly due to invasion of new species. Altogether 10 species of amphipods were recorded at 43 sites in 2013-2015. Invasive species of amphipods were dominated by biomass (40\% of the total benthic biomass) and occupied an important position in the coastal food chain of the gulf. The most abundant species such as Pontogammarus robustoides, Gmelinoides fasciatus and Gammarus tigrinus attributed to be omnivorous or carnivorous animals, changing their diet during ontogenesis. Adult males of these species preyed actively upon coexisting species of invertebrates reducing their abundance. At the same time, young and middle-sized individuals of amphipods, consuming a significant amount of detritus and algae, promote their rapid transformation, making this resource more available to the other consumers.

Keywords: Amphipoda, abundance, biomass, diet, trophic position, ontogenetic shift.

DOI: $10.17516 / 1997-1389-2016-9-4-409-426$.

(C) Siberian Federal University. All rights reserved

* Corresponding author E-mail address: na-berezina@rambler.ru 


\section{Количественные характеристики}

\section{и пищевые предпочтения бокоплавов (Crustacea: Amphipoda) \\ в восточной части Финского залива}

Балтийского моря

Н.А. Березина, А.А. Максимов

Зоологический институт РАН

Россия, 199034, Санкт-Петербург, Университетская наб., 1

В данной статье рассмотрены амфиподы из группы эстуарных балтийских видов, в том числе их представленность в прибрежных и глубоководных сообществах восточной части Финского залива, и оченено их значение в трофических цепля. Актуальность работы определена слабой изученностью этой группы и вместе с тем значительным увеличением числа видов и их обилия в экосистеме Финского залива в последние годы в основном за счет вселения новых видов. В период изучения (2013-2015 гг.) на 43 станциях всего зарегистрировано 10 видов. Инвазионные амфиподы разных видов, недавно вселивщиеся в залив, доминировали по биомассе (около 40 \% всей биомассы зообентоса) и заняли важную позищию в прибрежных пищевых цепях. Maсcовые виды, Pontogammarus robustoides, Gmelinoides fasciatus u Gammarus tigrinus, отнесены к всеядным или хищным животным, меняющим свой способ и объекты питания в процессе онтогенеза. Взрослье особи этих видов - активные хищники, способные снижать численность сосуществующих с ними видов беспозвоночных. В то же время их молодь и особи среднего размера, потребляя в значительном количестве детрит и водоросли, способствуют их переработке, делая этот ресурс доступным для других консументов.

Ключевые слова: Amphipoda, численность, биомасса, питание, трофические уровни, онтогенетическая дифференциация.

\section{Введение}

Структура экосистемы, определяемая устойчивыми связями между ее элементами, способна находиться в определенном стабильном состоянии при условии действия одного качества факторов среды и за счет постоянных затрат энергии на поддержание упорядоченности и воспроизводства ее элементов (Алимов, 2006). Переход экосистемы в другое состояние может быть обусловлен любым фактором, вызвавшим изменение ее структуры; при этом через некоторое время внутренние механизмы стабилизируют ее функционирование в ее новом состоянии. Появление новых видов в экосистеме - это мощный фактор, который неизбежно приводит к изменению разнообразия и возникновению новых трофических связей в экосистеме, что, в свою очередь, через изменение потока энергии ведет и к изменению ее функциональных характеристик.

Согласно определению в монографии (Алимов, Богуцкая, 2004) инвазионными (инвазивными), видами-вселенцами или чужеродными называют виды, вышедшие за пределы исторического ареала после неоли- 
та, находящиеся в процессе расселения или натурализации, а также натурализовавшиеся виды, расширяющие свой ареал. В Финском заливе Балтийского моря, включающем эстуарий р. Невы, отмечены массовые случаи появления организмов разных таксономических групп аллохтонного происхождения. Причины этого прежде всего связаны с развитием судоходства и строительством новых портов. Эстуарная часть Финского залива, сформированная в месте впадения p. Невы, - это область особого риска для проникновения инвазионных видов в Балтийское море из бассейнов Белого, Черного, Азовского и Каспийского морей, крупнейших озер (Ладожского, Онежского, Сайма) и рек (Волги, Дона, Днепра и Дуная). Несмотря на важность этой части залива, долгое время ее донная фауна была практически не изучена. Первые сведения о составе зообентоса и видах-вселенцах в Восточной Балтике (включая Финский залив) известны из работ 1950-1960-х гг.: С. Сегестрале, А.Т. Шурина, А. Ярвекюльга, И.И. Николаева и др., хотя они касались в основном финского и эстонского побережий (Алимов, Голубков, 2008). Детальные данные о зообентосе российской части Финского залива появились только в 1980-1990-х гг. (Анцулевич, Чивилев, 1992; Maximov, 2003).

В 1998 г. Зоологическим институтом РАН начаты и продолжаются по настоящее время ежегодные исследования российской части Финского залива (Алимов, Голубков, 2008; Maximov, 2011; Berezina, Petryashev, 2012 и др.). Анализ фауны залива за 1998-2008 гг. показал, что общее число видов-вселенцев в этой акватории достигло 51, или 5 \% от общего видового богатства (Алимов, Голубков, 2008).

Увеличение доли таких видов в Балтийском море в XX в. прежде всего связано с природной видовой бедностью водоема и, возможно, обусловлено его текущим эвтрофированием и увеличением первичной продукции экосистемы. Преднамеренные интродукции для улучшения кормовой базы рыб - важный вектор проникновения многих видов ракообразных в Балтийский регион. Самые грандиозные работы по преднамеренной интродукции амфипод, мизид и декапод, относящихся к разным фаунистическим комплексам, проводили в 1950-1970-х гг. в СССР. Например, во внутренние водоемы СССР вселено два реликтовых вида из Карелии, >30 видов амфипод из Понто-Каспийского региона и три - из Байкальской области (Berezina, 2007a).

Вселение видов, способных достичь высокого обилия в новых условиях, зачастую приводит к перестройке пищевых сетей и существенной трансформации структуры сообществ водных организмов. Например, следствием вселения гребневика Mnemiopsis leidyi A. Agassiz, 1865 в Черное море стало падение количества кормового для рыб мезозоопланктона и личинок пелагических рыб. Следствием появления гребневика M. leidyi и конкуренции с ним за пищу (зоопланктон) стало снижение численности рыб-зооплантофагов и представителей всех более высоких звеньев пищевой сети (Shiganova, 2005). Восстановление видового разнообразия и стабильности экосистемы в Черном море началось лишь после интродукции другого хищного гребневика - Beroe ovata Bruguiere, 1789, питающегося M. leidyi. Исследования роли недавних видоввселенцев амфипод и мизид также свидетельствуют об их негативном воздействии на численность сосуществующих беспозвоночных из-за хищничества (Kelly, Dick, 2005; Fink et al., 2012).

Использование балансового подхода для изучения трофодинамики водных экосистем позволяет упорядочить многочисленные тро- 
фические связи в экосистеме, преобразовав их в систему трофических уровней, не нарушающих законы термодинамики. Однако в случае оценки влияния хищников на популяции жертв и изучения конкуренции симпатрических видов, что особенно важно для оценки роли вида-вселенца в реципиентной экосистеме, необходимо учитывать и динамическую изменчивость характеристик (Голубков, 2006). Так, С. Дженнингс (Jennings et al., 2002) показал, что трофический уровень бентосных животных в сообществе может меняться с размерами и биомассой консументов соответственно во времени или пространстве, когда меняется структура их популяции. Б. Фрай (Fry, 1983) выявил разницу в источниках пищи и занимаемом трофическом уровне (по изотопному составу $\delta^{15} \mathrm{~N}$, $\delta{ }^{13} \mathrm{C}$ ) между молодью и взрослыми креветками на мелководьях в Мексиканском заливе. В водоемах Северо-Запада России спектр питания амфипод изменялся с увеличением размеров тела (Berezina, 2007b).

В связи с изменениями, отмеченными в фауне бокоплавов водных экосистем Северо-Запада России, включая Балтийское море (Berezina, Petryashev, 2012; Takhteev et al., 2015), основной задачей данной работы стало изучение роли разных видов амфипод в природных сообществах эстуарной части Финского залива, в первую очередь показателей обилия и питания. Данных по питанию разных групп донных животных, в том числе ракообразных, в восточном регионе Балтийского моря сравнительно немного (Burukovsky, 2012; Lesutiene et al., 2014; Golubkov, Tiunov, 2015). К тому же для многих видов амфипод показан смешанный характер питания и способность переходить от сапрофагии и фитофагии к хищничеству при наличии подходящей пищи (MacNeil et al., 1997). В связи с этим виды с таким типом питания, способные хищничать, требуют особого внимания.

\section{Материалы и методы}

Район исследований

Протяженность Финского залива Балтийского моря около 400 км, общая площадь

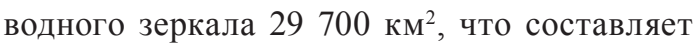
$7 \%$ от общей площади Балтийского моря. Наибольшие глубины (80-100 м) отмечены в его западной и южной частях, с максимумом 123 м. Район залива, располагающийся восточнее о. Гогланд, принято называть восточной частью Финского залива (ВЧФЗ), площадь ее водного зеркала составляет

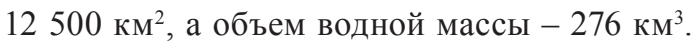
Максимальная глубина ВЧФЗ достигает до 70 м в районе о. Гогланд, затем в восточном направлении от острова происходит уменьшение глубин. Река Нева, впадающая в залив, влияет на гидролого-гидрохимический режим Финского залива. В его восточной части формируется один из крупнейших эстуариев Балтийского моря с градиентом солености воды от 0,05 (пресная) до 8,5 г/л (солоноватая). Невская губа (400 км²) - это самая восточная мелководная (средняя глубина 3 м, максимальная - до 6 м) часть залива. Она отделена от остальной акватории искусственно сооруженными дамбами комплекса защитных сооружений (КЗС) г. Санкт-Петербурга от наводнений. Невская губа является пресноводной, с содержанием солей в воде 0,05-0,5 г/л. Мелководный район ВЧФЗ (около $1000 \mathrm{kм}^{2}$ ) расположен от Невской губы до разреза «мыс Шепелевский - мыс Флотский». Важно отметить, что экосистема ВЧФЗ эвтрофируется под влиянием человека. С 1990 по 2005 г. со стоком p. Невы в залив поступило 30 тыс. т общего фосфора и 138 тыс. т азота (Алимов, Голубков, 2008). 


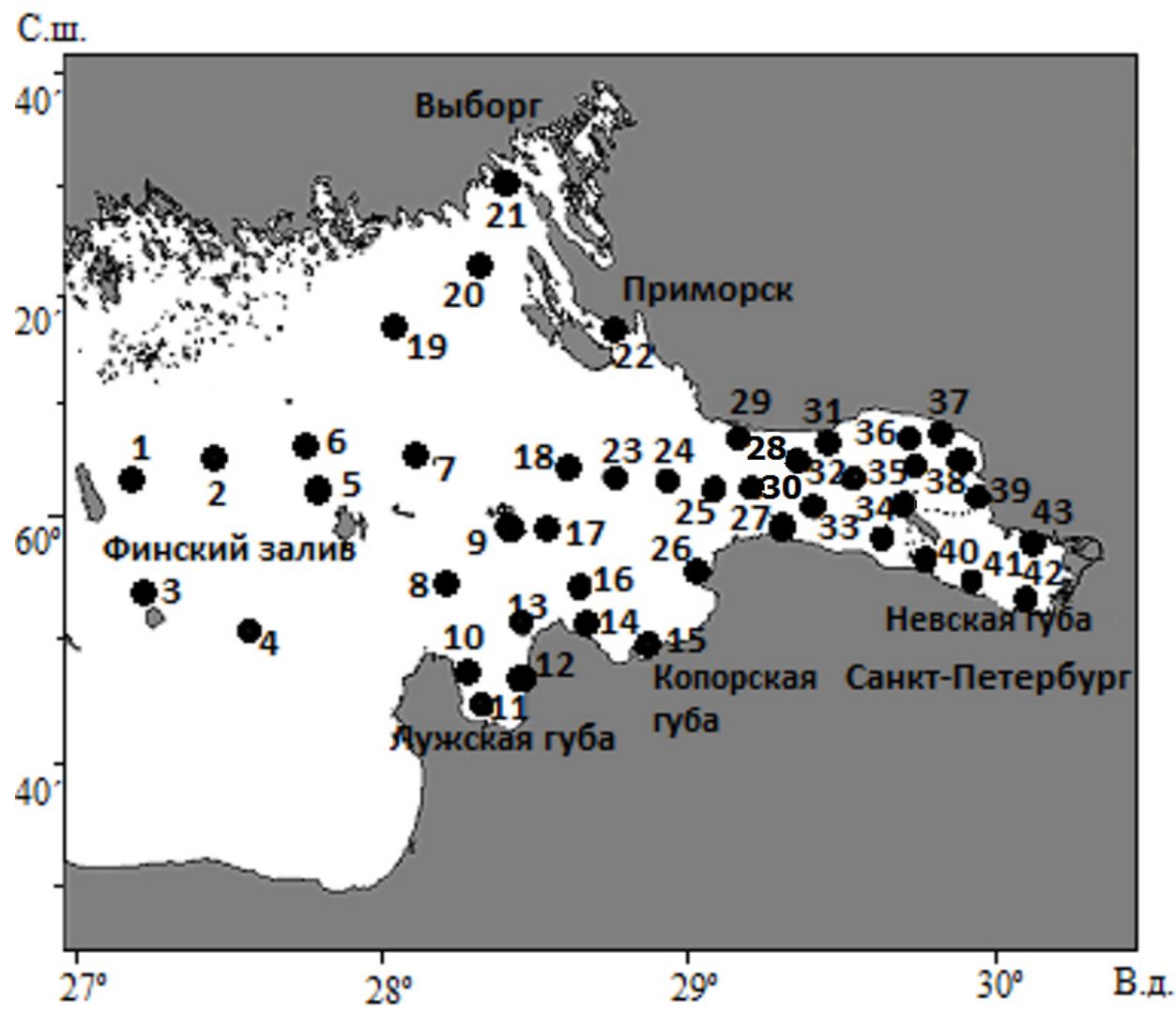

Рис. 1. Карта-схема Финского залива в районе исследования донных отложений с указанием месторасположения станций отбора проб (1-43)

Сбор проб проводили на 43 станциях (рис. 1) с глубинами 0,5-5 м в прибрежных биотопах и от 10 до 68 м в глубоководной части залива. Тип поверхностных осадков в центральной части акватории ВЧФЗ представлен алевритовыми песками до глубин 8 м, переходя глубже в алевро-пелитовые илы. На большей части Невской губы с глубинами $<5$ м типичны аккумулятивные волновые образования - мелкозернистые пески. В прибрежье (0-3 м) преобладали каменисто-песчаные грунты.

\section{Отбор и первичная обработка проб}

Пробы амфипод и бентоса собраны в июле и августе 2013-2015 гг. в российской части Финского залива. В глубоководной зоне сбор осу- ществлялся в ходе научно-исследовательских рейсов на судне «СН-1303 (Росприроднадзор)» и катамаране «Центаурус-2». Отбор проб на глубоководных станциях с преобладанием мягких грунтов (в основном илов) проводили дночерпателем Ван-Вина (площадью захвата $0,025 \mathrm{~m}^{2}$ ). В прибрежье пробы отбирали штанговым дночерпателем (Заболоцкого или Экмана- Берджа) с площадью захвата 0,025 м² на песчаных и илистых грунтах. Для отбора проб на каменисто-песчаных и каменистых субстратах в зоне 0-0,5 м использовали специальный трубчатый пробоотборник с площадью 0,03 м². Пробы с каменистых субстратов на глубинах 1-3 м собраны водолазом с помощью квадратной рамки (400 см²), оснащенной капроновой сетью с размером ячеи 250 мкм. 
Для каждой станции пробы отбирали в трех повторностях. Пробы промывали, используя сито (диаметром ячеи 500 мкм), и хранили в герметичных пластиковых пакетах, зафиксировав 10\%-ным формальдегидом.

В лаборатории из проб выбирали всех животных, подсчитывали и взвешивали на торсионных весах. Для данной работы рассчитывали абсолютную численность и биомассу всех видов амфипод и оценивали долю амфипод и других доминирующих групп ( \%) в биомассе бентоса.

\section{Изучение спектра питания амфипод}

Состав пищи массовых видов амфипод исследовали с учетом длины тела методом микроскопического анализа содержимого кишечников. Особи каждого изученного вида были собраны в заливе в районах с высоким обилием вида, поскольку для исследования требовалось не менее 30 экз. рачков каждого размерного ранга (с шагом в 1 мм). Длину амфипод (мм) измеряли под микроскопом от основания антенн до основания тельсона. После этого кишечник осторожно извлекали из тела рачка, используя микроиглу и пинцет, и расчленяли, распределяя содержимое в капле глицерина на предметном стекле. Рассчитывали частоту встречаемости (\%) того или иного пищевого компонента (детрита, растений и беспозвоночных) в общем количестве проанализированных кишечников рачков каждой размерной группы. Неорганический материал (грунт) был найден во всех кишечниках, но не учитывался как пищевой компонент. При представлении результатов приведен диапазон встречаемости каждого типа пищи, поскольку всех рачков объединили в три размерные группы: молодь (3-6 мм), взрослые особи I (7-12 мм) и взрослые особи II (>13 мм). У амфипод изученных видов самцы, как правило, крупнее самок; они попадали главным образом в третью группу.

Для оценки трофической позиции (уровня) видов-доминантов (>10\% по биомассе и численности) залива использовали метод анализа стабильных изотопов азота $\left({ }^{15} \mathrm{~N} /{ }^{14} \mathrm{~N}\right)$ в теле этих животных. Пробы детрита и живых растений и животных были отобраны на прибрежных и глубоководных станциях с выраженным доминированием амфипод. Все образцы были тщательно отмыты от эпибионтов и грязи. Для того чтобы уменьшить коэффициент вариации, в каждой пробе для анализа было совмещено несколько особей одного вида беспозвоночных или рыб. Образцы были высушены в термостате при температуре $50{ }^{\circ} \mathrm{C}$ в течение 48-72 ч. После высушивания пробы гомогенизировали пестиком в ступке. Навески в 0,5 мг для животной ткани и 1,5 мг для растительной ткани (и детрита) были взвешены на весах Mettler Toledo MX 5 с точностью \pm 1 мг и помещены в маленькие оловянные капсулы для анализа стабильных изотопов. Анализ проводил д.б.н. А.В. Тиунов в ЦКП ИПЭЭ РАН (г. Москва) на комплексе, состоящем из изотопного масс-спектрометра Thermo Finnigan Delta V Plus (Германия) и элементного анализатора (Thermo Scientific Flash EA 1112).

Изотопный состав азота в тканях амфипод рассчитан по соотношению его тяжелых и легких изотопов в пробе (проб.) и общепринятом стандарте (станд.) по формуле

$$
\delta^{\mathrm{n}} \mathrm{N}(\%)=\left(\mathrm{R}_{\text {проб }} / \mathrm{R}_{\text {станд. }}-1\right) \times 1000,
$$

где $\mathrm{n}$ - масса более тяжелого изотопа; $\mathrm{R}$ соотношение тяжелых и легких изотопов $\left({ }^{15} \mathrm{~N} /{ }^{14} \mathrm{~N}\right)$.

Для расчета трофического уровня, занимаемого в сообществе амфиподами, использовали величину соотношения изотопов азота. 
Величина трофического фракционирования (обогащения при переходе на один трофический уровень) была принята для изотопов азота $\left(\delta^{15} \mathrm{~N}\right)$ как $3.4 \%$ согласно Д.М. Посту (Post, 2002). Трофический уровень (TL) консумента был рассчитан по уравнению

$$
\mathrm{TL}=\left(\delta^{15} \mathrm{~N}_{\mathrm{c}}-\delta^{15} \mathrm{~N}_{\mathrm{b}}\right) / 3,4+2,
$$

где $\delta^{15} \mathrm{~N}_{\mathrm{c}}$ - изотопное отношение для искомого консумента и $\delta^{15} \mathrm{~N}_{\mathrm{b}}$ - базовое значение изотопного соотношение для первичного консумента (т.е. второго трофического уровня).

Предварительное изучение питания особей ювенальных стадий ( $<5$ мм) у амфипод Gmelinoides fasciatus (Stebbing, 1899) из литорали залива позволяет считать эту группу типичными детритоядами с TL - 2,0. Следовательно, их изотопный сигнал $\left(\delta{ }^{15} \mathrm{~N}_{\mathrm{b}}=\right.$ $6,8 \pm 0,1 \%$ б) был принят как базовый уровень для первичных консументов, и относительно его рассчитывали TL для остальных амфипод и рыб.

При расчете TL амфипод Monoporeia affinis (Lindstrom, 1855), Gammarus zaddachi Sexton, 1912 из батиали залива (глубже 12 м) использовали данные по $\delta^{15} \mathrm{~N}$ из работы (Голубков, Тиунов, 2015), поскольку эти рачки были собраны в 2013 г. одновременно с остальными представителями. Первичными консументами считали олигохет $\left(\delta^{15} \mathrm{~N}_{\mathrm{b}}=6,6 \pm 0,4 \%\right.$ ), и их изотопный сигнал принимали за базовый уровень.

\section{Результаты и обсуждение}

Представленность амфипод

в Финском заливе

Фауна амфипод бассейна Балтийского моря подробно изучалась с конца XIX столетия (Яржинский, 1890, цит. по Алимов, Голубков, 2008). До 60-х гг. прошлого столетия 4 вида, Gammarus pulex (Linnaeus, 1758),
Gammarus lacustris G.O. Sars, 1864, Monoporeia affinis и Pallasea quadrispinosa G.O. Sars, 1867, были обычны в эстуарии р. Невы (Дерюгин, 1925, цит. по: Алимов, Голубков, 2008). В 2013-2015 гг. всего в российской части Финского залива обнаружено 10 видов разноногих ракообразных отряда Amphipoda. Четыре вида из них, Gammarus tigrinus Sexton, 1939, Chelicorophium curvispinum (Sars, 1895), Pontogammarus robustoides (Sars, 1894) и Gmelinoides fasciatus, относятся к видамвселенцам. Остальные виды (табл. 1) - это типичные обитатели эстуарных областей Балтийского моря (Takhteev et al., 2015).

В глубоководной части залива массовыми были M. affinis и Corophium volutator (Pallas, 1766). Из литоральных видов характерны бореальные Gammarus zaddachi, G. oceanicus Segerstrale, 1947, G. duebeni Lilljeborg, 1852 и Bathyporeia pilosa Lindstrom, 1855. Они достигали высоких биомасс в осолоненных частях залива при солености воды $>2 \%$.

Типичные в прошлом для ВЧФЗ амфиподы Pontoporeia femorata Krøyer, 1842 и для Невской губы P. quadrispinosa в исследованных пробах не встречались. В 20052006 гг. P. femorata изредка (12-88 экз/м²) отмечались на глубинах 50-68 м в районе ст. 1 . P. quadrispinosa попадалась в 2004-2008 гг. у южного побережья у ст. 42 (16-32 экз/м²).

Gmelinoides fasciatus стал первым видомвселенцем в бассейне Балтийского моря среди амфипод в результате их преднамеренной интродукции в 1960-70-х гг. в озера Карельского перешейка. До начала 1960-х гг. ареал этого вида был ограничен бассейнами сибирских рек (Ангара, Баргузин, Иртыш, Лена, Пясина, Тунгуска, Селенга, Енисей). В пресноводной Невской губе G. fasciatus отмечен впервые в 1996 г.; в олигогалинной части эстуария p. Невы - в 1999 г. и в устье р. Нарвы - в 2000 г. (Berezina, Petryashev, 2012). 
Таблица 1. Список видов бокоплавов, их встречаемость на изученных станциях, численность и биомасса в летних сборах 2013-2015 гг. Над чертой приведены минимальные и максимальные значения численности $(\mathrm{N})$ и биомассы (B), под чертой - их средние значения \pm стандартная ошибка. Для редких видов, обнаруженных на 2-3 станциях, средние величины не рассчитывали (-)

\begin{tabular}{|c|c|c|c|c|}
\hline Вид & Номера станции & Глубина, м & $\mathrm{N}\left(\right.$ экз $\left./ \mathrm{M}^{2}\right)$ & $\mathrm{B}\left(\Gamma / \mathrm{M}^{2}\right)$ \\
\hline Bathyporeia pilosa & 3,9 & $0-5$ & $\frac{180-920}{-}$ & $\frac{0,36-2,48}{-}$ \\
\hline Monoporeia affinis & $\begin{array}{l}2,4,5-8,10,16-19,21,23- \\
25,28,30,32-33,35\end{array}$ & $14-60$ & $\frac{20-1260}{490 \pm 70}$ & $\frac{0,01-2,66}{1,13 \pm 0,23}$ \\
\hline Corophium volutator & 10,23 & $10-23$ & $\frac{10-5080}{-}$ & $\frac{0,05-10,50}{-}$ \\
\hline Chelicorophium curvispinum & $12,15,27$ & $0-3$ & $\frac{10-160}{75 \pm 41}$ & $\frac{0,05-3,00}{1,13 \pm 0,90}$ \\
\hline Pontogammarus robustoides & $\begin{array}{l}12,14-15,26-27,31,37 \\
39-42\end{array}$ & $0-3$ & $\frac{32-5150}{860 \pm 287}$ & $\frac{0,48-10,70}{3,14 \pm 0,65}$ \\
\hline Gmelinoides fasciatus & $37,39-43$ & $0-3$ & $\frac{64-2880}{580 \pm 160}$ & $\frac{0,12-10,60}{2,48 \pm 0,62}$ \\
\hline Gammarus tigrinus & $\begin{array}{l}12,15,22,26-27,29,31 \\
37,40\end{array}$ & $0-3$ & $\frac{32-1220}{380 \pm 210}$ & $\frac{0,22-5,44}{2,72 \pm 0,93}$ \\
\hline Gammarus zaddachi & $10-12,14$ & $0-23$ & $\frac{32-74}{-}$ & $\frac{0,24-0,62}{-}$ \\
\hline Gammarus oceanicus & $12,21,22$ & $0-26$ & $\frac{21-106}{-}$ & $\frac{0,21-1,07}{-}$ \\
\hline Gammarus duebeni & 12,15 & $0-3$ & $\frac{10-32}{-}$ & $\frac{0,10-0,22}{-}$ \\
\hline
\end{tabular}

Два вида из Понто-Каспийского фаунистического комплекса, C. curvispinum и P. robustoides, встречаются в заливе при солености 0,2-5 \%о. Область их анцестрального ареала включает прибрежные опресненные участки трех южных морей: Черного, Азовского и Каспийского, приустьевые участки и эстуарии южных рек (Волга, Дон, Буг, Днепр, Днестр, Дунай и др.). Появление P. robustoides в бассейне Балтийского моря произошло в 1960-х гг. в результате преднамеренной интродукции из бассейна Черного моря (в том числе Симферопольского водохранилища) в Каунасское водохранилище (на р. Неман). Затем после успешной акклиматизации он был вселен в различные внутренние водоемы Литвы, Латвии и СевероЗапада России (Berezina, 2007a). Основным способом заноса корофииды C. curvispinum в Балтийское море из южных широт считается перевозка с судами и саморасселение (Berezina, Petryashev, 2012). Амфиподы P. robustoides впервые отмечены в Невской губе в 1999 г. (Berezina, Petryashev, 2012); в этот же период они были обнаружены в Нарвском заливе и у эстонского побережья Балтики (Herkul et al., 2009). Chelicorophium curvispinum был впервые выявлен в российской части Финского залива (Лужской губе) в 2006 г. (Малявин и др., 2008).

Вселенец из Атлантического побережья Северной Америки G. tigrinus был впервые отмечен в Балтийском море в 1975 г. (Bulnheim, 1976, цит. по Berezina, 2007c). В 1990-х гг. он широко расселился в водах южной и восточной Балтики. В эстуарий р. Невы, где G. tigrinus отмечен впервые в 2005 г., скорее всего, привезен с балластными водами судов из других 
районов Балтийского моря (Berezina, 2007c). По-видимому, этот рачок легко и быстро адаптируется к условиям новых мест, что привело к быстрому освоению им всего эстуария уже в 2006-2009 гг. (Berezina, Petryashev, 2012). Gammarus tigrinus в Невской губе встречается локально - на юге у КЗС, а в открытой части Финского залива - повсеместно.

Несколько видов, отмечавшихся в предыдущие годы в Финском заливе, таких как Chaetogammarus warpachowskyi Sars, 1897 и Gammarus lacustris, в пробах 2013-2015 гг. не обнаружено. Несколько экземпляров понтокаспийской амфиподы C. warpachowskyi, массовой в южной части Балтийского моря, было обнаружено в 2004 г. в Финском заливе. Gammarus lacustris ранее был обычен (до 720 экз $/$ м² $^{2} 1984$ г.) в северной части Невской губы в районе Морская-Ольгино (Панов, 1988), а к настоящему времени его можно считать исчезнувшим. Отсутствие в изученной зоне G. lacustris было отмечено уже в 1996 г., когда впервые обнаружили байкальского вселенца G. fasciatus (Panov et al., 1999). Видимо, при сосуществовании аборигенного гаммаруса и вселенца со сходной жизненной стратегией проявился принцип конкурентного исключения.

В ручьях на заливных участках побережья Финского залива и устьях малых рек встречается G. pulex (с невысокой численностью 16-128 экз $/ \mathrm{M}^{2}$ ), а в выбросах макрофитов - Orchestia cavimana (Heller, 1865). По мнению К. Херкул с соавторами (Herkul et al., 2006), последний вид проник в 1999 г. в северо-восточную часть Балтики из южных районов моря с плавающими матами макрофитов и балластными водами. К настоящему времени талитрида O. cavimana стала обычным видом в разных частях моря. В 2010 г. она отмечена в выбросах макрофитов в Лужской губе (Berezina, Petryashev, 2012).
Распределение по численности и биомассе разных видов амфипод в акватории наблюдений было неравномерно (табл. 1). Большинство видов обитают в прибрежной части залива с глубинами менее 5 м; из них G. fasciatus и P. robustoides (до 10 г/ $\mathrm{M}^{2}$ ) и Gammarus tigrinus (до 5 г/м²) были наиболее многочисленными. Bathyporeia pilosa в массе отмечена на песчаных отмелях вблизи островов Большой Тютерс (ст. 3) и Сескар (ст. 9), что было нехарактерно для этого вида в предыдущие годы. Монопорея M. affinis - типичный обитатель батиали, она была встречена на 90 \% изученных станций, достигая максимально 1260 экз/ $\mathrm{M}^{2}$ и 2,7 г/м² (табл. 1). Корофиум C. volutator также достигал высокой биомассы $(10$ г/м²) в отдельных местообитаниях (Лужской губе).

Средние биомассы макрозообентоса почти в 4 раза выше в батиали $(55 \pm 9$ г/м²), чем в литорали $\left(14 \pm 4\right.$ г $\left./ \mathrm{M}^{2}\right)$. Биомассы прибрежных амфипод более чем в 5 раз превышали биомассы амфипод в батиали (рис. 2). Амфиподы доминировали в прибрежье как пресноводной Невской губы (от 1,6 до 5 г/M²), так и открытой

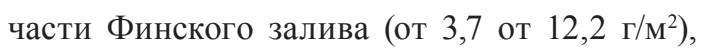
достигая в среднем $41 \%$ от биомассы макрозообентоса (рис. 3). В батиали доля амфипод в биомассе макрозообентоса была около $2 \%$ (рис. 3), а высоких биомасс достигали крупные балтийские виды, моллюски Масота baltica (Linnaeus, 1758) и изоподы Saduria entomon (Linnaeus, 1758), а также недавние вселенцы, полихеты рода Marenzellaria, в основном, Marenzelleria arctia (Chamberlin, 1920) (Maximov, 2011).

Полученные различия в распределении амфипод по акватории и их численности в разных частях эстуария р. Невы могут быть связаны с разной соленостью воды. Экспериментально было показано, что размножение пресноводного G. fasciatus байкальского про- 


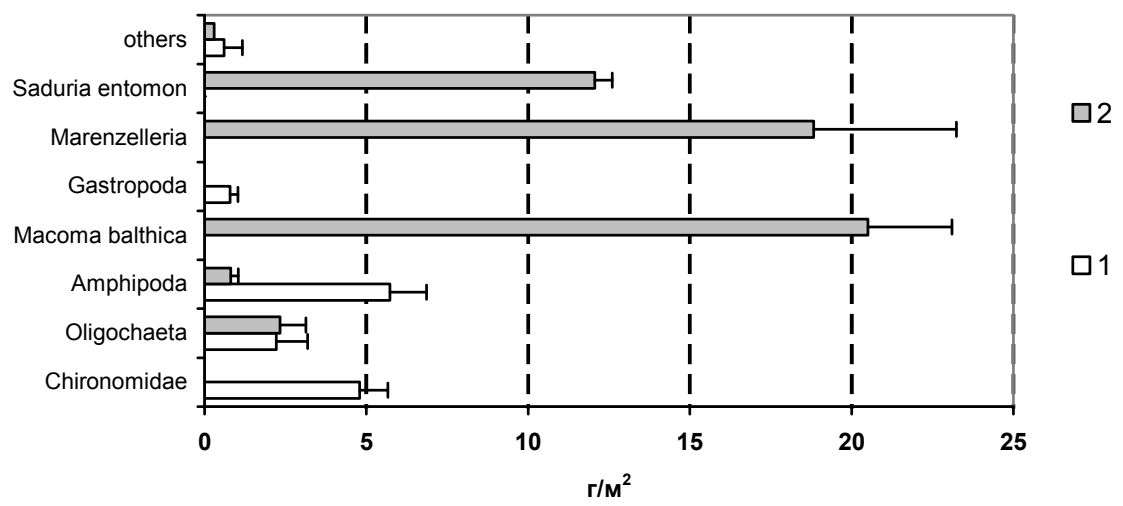

Рис. 2. Средние биомассы разных видов и групп донных животных в прибрежной (1) и глубоководной (2) зонах восточной части Финского залив

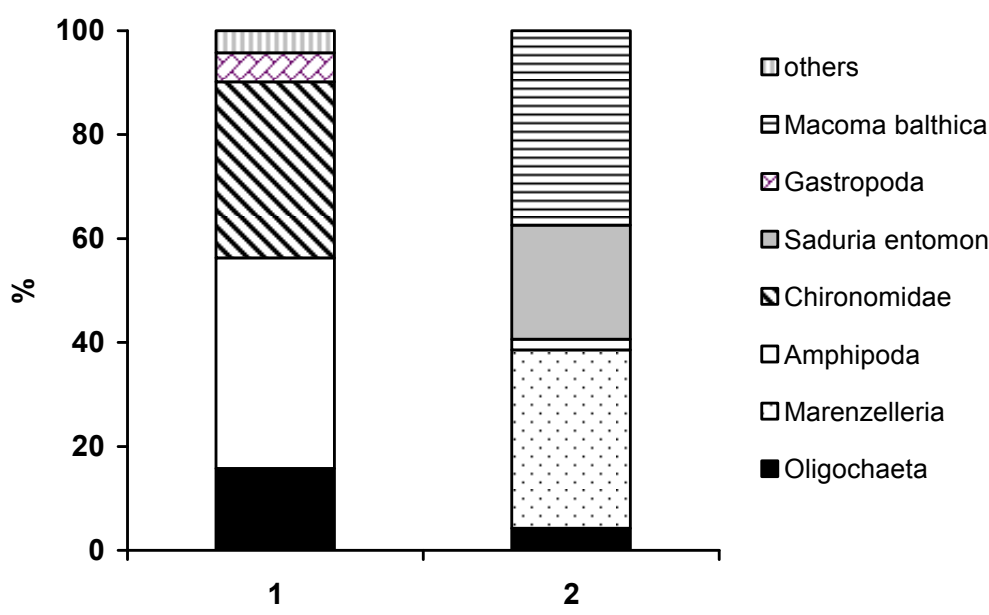

Рис. 3. Доля средних биомасс (\%) разных видов и групп животных в макрозообентосе прибрежной (1) и глубоководной (2) зон восточной части Финского залива (по данным 2014 г.)

исхождения ограничено соленостью воды более $2 \%$ (Berezina et al., 2001). В пресноводных местообитаниях численность и биомасса байкальских амфипод были выше, чем в других частях эстуария.

Максимальных биомасс вселенцы P. robustoides и G. fasciatus достигали в открытом заливе (за КЗС), они были существенно ниже для обоих видов в Невской губе. Байкальский вид характеризовался самым высоким развитием (в среднем 2500 экз $/ \mathrm{M}^{2}$ и 10 г/м²) на ст. 9 (парк Дубки), и на сегодняшний момент это одно из немногих оставшихся местообитаний G. fasciatus, где он обилен. Численность понтогаммаруса, способного вытеснять G. fasciatus (Berezina, Panov, 2003), на этой станции низка (3264 экз $\left./ \mathrm{M}^{2}\right)$. Для этих двух видов наблюдается явление экологического разобщения, как и в других случаях сосуществования олигогалинных и пресноводных амфипод, например в пределах Каспийско-Азово-Черноморского бассейна (Мордухай-Болтовской, 1960). Вытесненным всегда оказывается вид, который 
попал в условия, близкие к границе его толерантности к фактору, в данном случае к солености. Таким образом, байкальский вселенец получил преимущество в пресных, а понто-каспийский - в олигогалинных участках залива.

На биомассу амфипод на больших глубинах влияет гипоксия, которая периодически развивается в периоды затоков соленых обедненных кислородом вод из Северного моря. Как показано А.А. Максимовым (Maximov, 2015), после затоков существенно снижалась биомасса макрозообентоса в батиали, вплоть до образования обширных безжизненных зон. Хотя амфипода M. affinis (реликт ледникового периода) - это один из наиболее широко распространенных и обильных видов в глубоководных (при 4-5 $\mathrm{C}$ ) местообитаниях Балтийского моря, она крайне чувствительна к низкому содержанию кислорода $(<4$ мг О/л) (Wiklund, Sundelin, 2001). В отношении M. affinis положительная корреляция получена между выживаемостью и содержанием кислорода в придонной воде (Berezina et al., 2013). В связи с гипоксией в 2000-х гг. в Финском заливе отмечено резкое снижение численности этого вида и также P. femorata (Maximov, 2003; Laine et al., 2007). По данным, полученным нами, можно заключить, что на современном этапе популяция $M$. affinis в восточной части залива восстанавливает свою численность.

На некоторых станциях в литорали (ст. 14, 22, 31) на выживаемость амфипод и, соответственно, их обилие, оказывали негативное влияние нитчатки - Cladophora glomerata (Linnaeus) Kutzing, 1843, Pylaiella littoralis (Linnaeus) Kjellman, 1872, которые достигают высоких биомасс. Во время разложения этих нитчаток отмечали снижение кислорода у дна до $<3$ мгО/л (Gubelit, Berezina, 2010), что вызвало высокую смертность всех донных беспозвоночных (Berezina, Golubkov, 2008; Berezina, 2008).

\section{Пищеввые предпочтения амфипод \\ и роль в трофической изепи \\ Финского залива}

Таблица 2 содержит частоты встречаемости различных категорий пищи в кишечниках у массовых видов амфипод Gammarus tigrinus, G. zaddachi, G. duebeni, G. oceanicus, G. fasciatus, P. robustoides. По составу содержимого кишечников все изученные виды амфипод отнесены к всеядным организмам со смешанным типом питания. При этом частота встречаемости животной и растительной пищи менялась с размерами тела рачков, а детрит присутствовал в кишечниках всех изученных особей. Детрит и растительная пища (водоросли) и представляли основу питания молоди амфипод G. fasciatus, P. robustoides и рода Gammarus и всех стадий таких видов, как M. affinis, B. pilosa, C. curvispinum и C. volutator, составляя более 80 \% всех пищевых компонентов (табл. 2).

При повышении температуры от 10 до $23{ }^{\circ} \mathrm{C}$ у разных видов амфипод время прохождения пищи через кишечник сокращается с 8 до 1 ч и, следовательно, возрастает интенсивность питания (Грезе, 1977). Чем выше интенсивность питания (что наблюдается в летний период), тем меньше усвояемость пищи. При интенсивном питании детритом фекалии амфипод содержат непереваренные остатки, которые служат средой для развития бактерий и ценной пищей для детритофагов. Например, количество фекалий, выделяемых одной особью $P$. robustoides с массой 106 мг при питании кладофорой при температуре $17{ }^{\circ} \mathrm{C}$ составляет 2,5-4 мг/сут. По нашим наблюдениям и литературным данным (Сущеня, 1975; Грезе, 1977), фекалии амфипод потреблялись многими донными олигохетами, личинками 
Таблица 2. Частота встречаемости (\%) разных пищевых компонентов в кишечниках амфипод разных видов с учетом длины тела из литоральной зоны Финского залива

\begin{tabular}{|c|c|c|c|c|}
\hline Вид амфипод & Пищевой компонент & $\begin{array}{l}\text { Молодь } \\
\text { (3-6 мм) }\end{array}$ & $\begin{array}{c}\text { Взрослые I } \\
\text { (7-12 мм) }\end{array}$ & $\begin{array}{c}\text { Взрослые II } \\
\text { (>13 мм) }\end{array}$ \\
\hline Gammarus tigrinus & \begin{tabular}{|l} 
Детрит \\
Растительная пища \\
Беспозвоночные
\end{tabular} & $\begin{array}{l}100 \\
28-100 \\
0-5\end{array}$ & $\begin{array}{l}100 \\
30-70 \\
6-39\end{array}$ & $\begin{array}{l}100 \\
40-78 \\
48-60\end{array}$ \\
\hline Gammarus zaddachi & $\begin{array}{l}\text { Детрит } \\
\text { Растительная пища } \\
\text { Беспозвоночные }\end{array}$ & $\begin{array}{l}100 \\
25-100 \\
0\end{array}$ & $\begin{array}{l}100 \\
20-55 \\
5-15\end{array}$ & $\begin{array}{l}100 \\
25-40 \\
14-54\end{array}$ \\
\hline Gammarus duebeni & $\begin{array}{l}\text { Детрит } \\
\text { Растительная пища } \\
\text { Беспозвоночные }\end{array}$ & $\begin{array}{l}100 \\
80-100 \\
0\end{array}$ & $\begin{array}{l}100 \\
100 \\
0-10\end{array}$ & $\begin{array}{l}100 \\
100 \\
17-67\end{array}$ \\
\hline Gammarus oceanicus & $\begin{array}{l}\text { Детрит } \\
\text { Растительная пища } \\
\text { Беспозвоночные }\end{array}$ & $\begin{array}{l}100 \\
100 \\
0-5\end{array}$ & $\begin{array}{l}100 \\
100 \\
6-17\end{array}$ & $\begin{array}{l}100 \\
100 \\
14-62\end{array}$ \\
\hline Pontogammarus robustoides & $\begin{array}{l}\text { Детрит } \\
\text { Растительная пища } \\
\text { Беспозвоночные }\end{array}$ & $\begin{array}{l}100 \\
100 \\
5-12\end{array}$ & $\begin{array}{l}100 \\
100 \\
15-65\end{array}$ & $\begin{array}{l}100 \\
0-30 \\
76-100\end{array}$ \\
\hline Gmelinoides fasciatus & $\begin{array}{l}\text { Детрит } \\
\text { Растительная пища } \\
\text { Беспозвоночные }\end{array}$ & $\begin{array}{l}100 \\
100 \\
0\end{array}$ & $\begin{array}{l}100 \\
25-100 \\
10-30\end{array}$ & $\begin{array}{l}100 \\
30-50 \\
25-50\end{array}$ \\
\hline Monoporeia. affinis & $\begin{array}{l}\text { Детрит } \\
\text { Растительная пища } \\
\text { Беспозвоночные }\end{array}$ & $\begin{array}{l}100 \\
100 \\
0\end{array}$ & $\begin{array}{l}100 \\
25-100 \\
10-30\end{array}$ & $\begin{array}{l}100 \\
30-50 \\
25-50\end{array}$ \\
\hline Bathyporeia pilosa & $\begin{array}{l}\text { Детрит } \\
\text { Растительная пища } \\
\text { Беспозвоночные }\end{array}$ & $\begin{array}{l}100 \\
0 \\
0\end{array}$ & $\begin{array}{l}100 \\
0 \\
0\end{array}$ & $\begin{array}{l}100 \\
30-60 \\
0\end{array}$ \\
\hline Chelicorophium curvispinum & $\begin{array}{l}\text { Детрит } \\
\text { Растительная пища } \\
\text { Беспозвоночные }\end{array}$ & $\begin{array}{l}100 \\
100 \\
0\end{array}$ & $\begin{array}{l}100 \\
100 \\
0\end{array}$ & $\begin{array}{l}100 \\
100 \\
0\end{array}$ \\
\hline Corophium volutator & $\begin{array}{l}\text { Детрит } \\
\text { Растительная пища } \\
\text { Беспозвоночные }\end{array}$ & $\begin{array}{l}100 \\
60 \\
0\end{array}$ & $\begin{array}{l}100 \\
100 \\
0\end{array}$ & $\begin{array}{l}100 \\
100 \\
0\end{array}$ \\
\hline
\end{tabular}

насекомых, молодью амфипод и изопод. Таким образом, массовое развитие амфипод в прибрежных экосистемах эстуариев Балтийского моря способствует переработке труднодоступного детрита и обогащению прибрежных биоценозов органическими веществами, доступными для других консументов, что может увеличивать общую продуктивность сообществ и запасов рыб.

Особи $>7$ мм (т.е. взрослые особи) большинства видов амфипод, помимо детрита и растительных остатков, включали в рацион и животную пищу (табл. 2) - мелких ракообраз- ных, олигохет, личинок насекомых. Пищевые компоненты животного происхождения найдены у $60 \%$ особей G. tigrinus , $54 \%-$ G. zaddachi, $62 \%$ - G. oceanicus и $67 \%-$ $G$. duebeni. Наиболее активными хищниками можно считать $P$. robustoides, у которых в питании 100 \% особей > 13 мм отмечены беспозвоночные.

В экспериментальных условиях показано, что особи $P$. robustoides активно нападают на ракообразных родов Asellus, Gmelinoides и других, на личинок поденок, хирономид, при этом их экологические рационы значитель- 
но превышают физиологические (Berezina, Panov, 2003). Беспозвоночные были отмечены в питании многих других видов амфипод сем. Gammaridae (Delong et al., 1993; Wilhelm, Schindler, 1999; Dick et al., 2005).

Частота встречаемости животной компоненты в питании амфипод - меняющаяся величина. У исследованных видов она, как правило, возрастала с увеличением длины тела и у самых крупных особей (преимущественно самцов) была максимальной. Например, 30-70 \% особей G. tigrinus с длиной тела 7-12 мм питались растительной пищей, а у 48$60 \%$ особей > 13 мм в кишечниках отмечены в основном беспозвоночные (олигохеты, хирономиды, ракообразные). Частоты встречаемости амфипод и других беспозвоночных составляли 33 и $67 \%$ соответственно в питании 14-16 мм особей G. duebeni. Различные беспозвоночные входили в состав пищи 70-90 \% крупных особей G. oceanicus (19-23 мм).

Сходные закономерности перехода к хищному питанию с увеличением размеров (массы) тела свойственны и другим ракообразным, обитающим в Балтийском море, например креветкам Palaemon elegans Rathke, 1837 (Буруковский, 2012; Lesutiene et al., 2014) и мизидам Paramysis lacustris (Czerniavsky, 1882) (Lesutiene et al., 2007).

В результате хищничества было отмечено значительное снижение численности G. fasciatus в местах совместного обитания его с P. robustoides в эстуарии р. Невы (Berezina, Panov, 2003). В других водоемах примеры вытеснения одного вида другим также наблюдали в случае сосуществования, например, для Gammarus fasciatus Say, 1818 и Gammarus pulex; G. pulex и G. lacustris; G. duebeni и Gammarus salinus Spooner, 1947; G. pulex и G. duebeni (Алимов, Богуцкая, 2004). Межгильдиевое хищничество относится к наиболее общим и типичным формам взаимодействия между амфиподами, и этот фактор рассматривается в качестве основного, объясняющего исключение одних видов другими.

В экспериментах по хищному питанию амфипод было показано, что хищный пресс возрастал с увеличением количества жертв. Так, при увеличении численности жертв $G$. duebeni от 3 до 15 экз/дм² экологические рационы хищника $G$. oceanicus возрастали в два раза, составляя 0,02-0,05 экз/ч, или 0,48-1,20 экз/сут. Также рационы Gmelinoides fasciatus при потреблении мелких изопод Asellus aquaticus (Linnaeus, 1758) варьировали от 0,28 до 1,07 экз/сут, возрастая с ростом количества жертв от 5 до 20 экз/дм². Одна особь Dikerogammarus villosus (Sowinsky, 1894) уничтожала от 9 до 15 изопод в сутки при численности последних 10-40 экз/дм², причем рационы этого хищника возрастали с ростом численности жертв (Bollache et al., 2008).

Изотопный анализ $\left(\delta^{15} \mathrm{~N}\right)$ позволил определить позицию в трофической сети Финского залива, занимаемую разными видами амфипод (табл. 3). Известно, что значения TL для детритоядных и растительноядных организмов находятся в пределах 2-2,5. Промежуточный уровень (TL = 2,5-3,0) занимают организмы со смешанным типом питания (всеядные), в их питании присутствует как животные, так и растительные компоненты. TL $=3$ и более свидетельствует о хищном питании организма. Была установлена межвидовая и внутривидовая разница в значениях TL. Молодь всех изученных видов отнесена к консументам первого порядка (TL 2-2,1). Для M. affinis выявлена небольшая разница в TL для молоди и более крупных (7-9 мм) взрослых особей. Однако этот вид отнесен к консументам первого порядка (TL 2,1-2,6), по-видимому, будучи исключительно детритоядным организмом в условиях батиали Финского залива. 
Таблица 3. Средние значения $\delta^{15} \mathrm{~N}(\%) \pm$ стандартная ошибка и трофический уровень (TL) амфипод разных видов и других компонентов пищевых цепей в восточной части Финского залива

\begin{tabular}{|c|c|c|}
\hline Вид, компонент & $\delta^{15} \mathrm{~N}$ & $\mathrm{TL}$ \\
\hline Детрит (растительный) & 5,3 & 1,0 \\
\hline Рдест Potamogeton perfoliatus & $4,2 \pm 0,1$ & 1,0 \\
\hline \multicolumn{3}{|c|}{ Батиаль } \\
\hline Олигохеты & $6,6 \pm 0,4$ & 2,0 \\
\hline $\begin{array}{l}\text { Monoporeia affinis } \\
4-6 \text { мм } \\
7-9 \text { мм }\end{array}$ & $\begin{array}{l}6,9 \\
8,8\end{array}$ & $\begin{array}{l}2,1 \\
2,6\end{array}$ \\
\hline $\begin{array}{l}\text { Gammarus zaddachi } \\
\text { 7-14 мм }\end{array}$ & $10,8 \pm 1,0$ & 3,2 \\
\hline \multicolumn{3}{|c|}{ Литораль } \\
\hline $\begin{array}{l}\text { Gmelinoides fasciatus } \\
4-6 \text { мм } \\
7-12 \text { мм } \\
13-15 \text { мм }\end{array}$ & $\begin{array}{l}6,8 \pm 0,1 \\
9,2 \pm 0,2 \\
9,3 \pm 0,1\end{array}$ & $\begin{array}{l}2,0 \\
2,7 \\
2,8\end{array}$ \\
\hline $\begin{array}{l}\text { Pontogammarus robustoides } \\
4-6 \text { мм } \\
7-12 \text { мм } \\
12-17 \text { мм }\end{array}$ & $\begin{array}{c}6,8 \pm 0,1 \\
8,5 \pm 0,1 \\
11,3 \pm 0,1\end{array}$ & $\begin{array}{l}2,0 \\
2,5 \\
3,3\end{array}$ \\
\hline $\begin{array}{l}\text { Gammarus tigrinus } \\
4-6 \text { мм } \\
7-12 \text { мм } \\
13-15 \text { мм }\end{array}$ & $\begin{array}{l}6,0 \pm 0,1 \\
7,6 \pm 0,1 \\
9,6 \pm 0,3\end{array}$ & $\begin{array}{l}2,0 \\
2,5 \\
2,8\end{array}$ \\
\hline $\begin{array}{l}\text { Chelicorophium curvispinum } \\
6-11 \text { мм }\end{array}$ & $8,6 \pm 0,1$ & 2,5 \\
\hline $\begin{array}{l}\text { Окунь Perca fluviatilis } \\
40-70 \text { мм }\end{array}$ & $14,5 \pm 0,1$ & 4,3 \\
\hline
\end{tabular}

Особи средних размеров G. fasciatus, P. robustoides, G. tigrinus, C. curvispinum (в основном половозрелые самки и молодые самцы) по занимаемому трофическому уровню $(2,5-2,7)$ относились к всеядным организмам. Третий трофический уровень (>3) был рассчитан для крупных особей $P$. robustoides и G. zaddachi. Это доказывает, что крупные особи этих видов переходят к облигатному хищничеству. В отличие от $P$. robustoides $u$ G. zaddachi амфиподы G. tigrinus и G. fasciatus сохраняли смешанный характер питания на всем протяжении жизни (TL $<3$, табл. 3). Для рыб (молоди окуня) трофический уровень определен как 4,27, что свидетельствует о питании изученными амфиподами и другими бентосными беспозвоночными, однако вопрос об использовании рыбами амфипод остается за рамками данной статьи и требует дальнейшего исследования.

\section{Заключение}

К настоящему времени амфиподы весьма значимы в биоценозах Финского залива, главным образом, благодаря вселению и размножению новых видов и восстановлению популяции балтийского вида Monoporeia affinis. Массовыми признаны виды аллохтонного происхождения, такие как Pontogammarus robustoides, Gmelinoides fasciatus и Gammarus 
tigrinus. По типу питания они отнесены к всеядным или хищным животным, меняющим свой способ питания и объекты питания в процессе онтогенеза. Взрослые особи этих видов - активные хищники, а молодь и особи среднего размера потребляют в значительном количестве детрит и водоросли. Полученные данные позволяют заключить, что вселение новых видов имеет двоякое последствие для сообществ и экосистемы залива. С одной стороны, вселенцы могут снижать численность и видовое богатство сообществ донных и планктонных беспозвоночных за счет выедания. Хищничество с их стороны или конкуренция за пищевые ресурсы, таким образом, могут привести к изменению структуры сообществ сосуществующих с ними видов беспозвоночных. С другой стороны, выявлено, что амфиподы относятся к основным потребителям детрита растительного происхождения и выполняют своего рода «очистительную» дея- тельность в прибрежной зоне, где в избытке этот детрит накапливается. В этом смысле увеличение роли амфипод в экосистеме Финского залива влияет положительно на других консументов, поскольку, перерабатывая детрит, амфиподы обогащают донные субстраты органическим веществом, легко доступным для других, поддерживая тем самым высокую продуктивность сообществ. В свою очередь, эти амфиподы составляют основу питания литоральных рыб.

\section{Благодарности}

Работа выполнена по теме ЗИН РАН (№ 01201351192), совместной программы РФФИ и Сообщества Балтийских организаций (BONUS EEIG) (проект COCOA) при финансовой поддержке грантов РФФИ (№ 14-0491721 БОНУС_а, 14-04-00207 и 13-04-00962).

Авторы благодарны д.б.н. А.В. Тиунову за анализ стабильных изотопов.

\section{Список литературы}

Алимов А.Ф. (2006) Заметки о современном состоянии гидробиологии континентальных водоемов. Известия Самарского научного иентра РАН, 8 (1): 7-17 [Alimov A.F. (2006) Notes on the current status of hydrobiology of continental water-bodies. Proceedings of the Samara Scientific Center of the Russian Academy of Sciences [Izvestiya Samarskogo Nauchnogo centra RAN], 8 (1): 7-17 (in Russian)]

Алимов А.Ф., Богуцкая Н.Г. (2004) Биологические инвазии в водных и наземных экосиcmемах. М., Товарищество научных изданий КМК, 436 с. [Alimov A.F., Bogutskaya N.G. (2004) Biological invasions in aquatic and terrestrial ecosystems. Moscow, KMK Scientific Press Publishers, 436 p. (in Russian)]

Алимов А.Ф., Голубков С.М. (2008) Экосистема эстуария реки Невы: биологическое разнообразие и экологические проблемы. М., Товарищество научных изданий КМК, 477 с. [Alimov A.F., Golubkov S.M. (2008) The ecosystem of the Neva River estuary: biological diversity and environmental problems. Moscow, KMK Scientific Press Publishers, 477 p. (in Russian)]

Анцулевич А.Е., Чивилев С.М. (1992) Современное состояние донной фауны Лужской губы Финского залива. Вестник СПбГУ. Биология, 3 (17): 3-7 [Antsulevich A.E., Chivilev S.M. (1992) The current state of the benthic fauna of the Luga Bay of the Gulf of Finland. Herald of St. Petersburg State University. Biology [Vestnik SPbGU Biologiya], 3 (17): 3-7 (in Russian)]

Буруковский Р.Н. (2012) О питании креветки Palaemon elegans Rathke 1837 (Decapoda, Palaemonidae) в Вислинском заливе. Журнал Сибирского федерального университета. Биология,

$$
-423-
$$


2: 151-159 [Burukovsky R.N. (2012) On Palaemon elegans Rathke, 1837 (Decapoda, Palaemonidae) nutrition in Vistula Lagoon. Journal of Siberian Federal University. Biology [Zhurnal Sibirskogo federalnogo universiteta. Biologiya], 2: 151-159 (in Russian)]

Голубков С.М. (2006) Трофодинамика континентальных водоемов от балансового подхода к динамической изменчивости экосистем. Известия Самарского научного изентра РАH, 8 (1): 18-25 [Golubkov S.M. (2006) Trophic dynamics of continental reservoirs: from the balance approach to the dynamic variability of ecosystems. Proceedings of the Samara Scientific Center of the Russian Academy of Sciences, 8 (1): 18-25 (in Russian)]

Голубков С.М., Тиунов А.В. (2015) Происхождение углерода в органическом веществе эстуария реки Нева. Доклады Академии наук, 465 (6): 753-755 [Golubkov S.M., Tiunov A.V. (2015) Origin of carbon in organic matter in the Neva estuary. Doklady Akademii Nauk [Doklady akademii nauk], 465 (6): 753-755 (in Russian)]

Грезе И.И. (1977) Амфиподы Черного моря и их биология. Киев, Наукова думка, 156 с. [Greze I.I. (1977) Amphipods of the Black Sea and their biology. Kiev, Naukova dumka, 156 p. (in Russian)]

Малявин С.А., Березина Н.А., Хванг Дж.-Ш. (2008) О находке Chelicorophium curvispinum Sars 1895 (Amphipoda: Crustacea) в Финском заливе Балтийского моря. Зоологический журнал, 87 (6): 643-649 [Malyavin S.A., Berezina N.A., Hwang J.-S. (2008) A finding of Chelicorophium curvispinum Sars 1895 (Amphipoda: Crustacea) in the Gulf of Finland, Baltic Sea. Zoological Journal [Zoologicheskyi zhurnal], 87 (6): 643-649 (in Russian)]

Мордухай-Болтовской Ф.Д. (1960) Каспийская фауна в Азово-Черноморском бассейне. М.-Л., Изд-во АН СССР, 288 с. [Mordukhai-Boltovskoj F.D. (1960) Caspian fauna in Azov-Black Sea basin. Moscow, Leningrad, AS USSR, 288 p. (in Russian)]

Панов В.Е. (1988) Рост и продукция бокоплавов. Сообщества пресноводных беспозвоночHblx в зарослях макрофитов. Алимов А.Ф (ред.) Л., ЗИН РАН, с. 150-160 [Panov V.E. (1988) Growth and production of amphipods. Communities of freshwater invertebrates in macrophytes beds. Alimov A.F. (ed.) Leningrad, Zoological Institute of the Russian Academy of Sciences, p. 150-160 (in Russian)]

Сущеня Л.М. (1975) Количественные закономерности питания ракообразных. Минск, Наука и техника, 207 c. [Suschenya L.M. (1975) Quantitative characteristics of crustaceans feeding. Minsk, Nauka i tekhnika, 207 p. (in Russian)]

Berezina N.A. (2007a) Invasions of alien amphipods (Amphipoda: Gammaridea) in aquatic ecosystems of North-Western Russia: pathways and consequences. Hydrobiologia, 590: 15-29

Berezina N.A. (2007b) Food spectra and consumption rates of four amphipod species from the North-West of Russia. Fundamental and Applied Limnology / Archiv fur Hydrobiologie, 168 (4): 317326

Berezina N.A. (2007c) Expansion of the North American amphipod Gammarus tigrinus Sexton, 1939 to the Neva Estuary (easternmost Baltic Sea). Oceanologia, 49 (1): 129-135

Berezina N.A. (2008) Spatial distribution of macrofauna in a littoral zone with drifting macroalgae in the Neva estuary. Estonian Journal of Ecology, 57 (3): 198-213

Berezina N., Golubkov S. (2008) Effect of drifting macroalgae Cladophora glomerata on benthic community dynamics in the easternmost Baltic Sea. Journal of Marine Systems, 74S: 80-85 
Berezina N.A., Panov V.E. (2003) Establishment of new gammarid species in the eastern Gulf of Finland and their effects on littoral communities. Proceedings of the Estonian Academy of Sciences, Biology, Ecology, 52 (3): 284-304

Berezina N.A., Petryashev V.V. (2012) Invasions of higher crustaceans (Crustacea: Malacostraca) in waters of the Gulf of Finland (Baltic Sea). Russian Journal of Biological Invasions, 3 (2): 81-91

Berezina N.A., Khlebovich V.V., Panov V.E., Zaporozhets N.V. (2001) Salinity tolerance of the amphipod Gmelinoides fasciatus (Stebb) introduced into the Gulf of Finland. Doklady Biological Sciences, 379 (1-6): 366-368

Berezina N., Strode E., Lehtonen K., Balode M., Golubkov S. (2013) Sediment quality assessment using Gmelinoides fasciatus and Monoporeia affinis (Amphipoda, Gammaridea) in the northeastern Baltic Sea. Crustaceana, 86 (7-8): 780-801

Bollache L., Dick J.T.A., Farnsworth K.D., Montgomery W.I. (2008) Comparison of the functional responses of invasive and native amphipods. Biology Letters, 4: 166-169

Delong M.D., Summer R.B., Thorp J.H. (1993) Influence of food type on the growth of a riverine amphipod Gammarus fasciatus. Canadian Journal of Fisheries and Aquatic Sciences, 50 (9): 18911896

Dick J.T.A., Jonson M.P., McCambridge S., Johnson J., Carson V.E.E., Kelly D.W., MacNeil C. (2005) Predatory nature of the littoral amphipod Echinogammarus marinus: gut content analysis and effects of alternative food and substrate heterogeneity. Marine Ecology Progress Series, 291: 151-158

Fink P., Kottsieper A., Heynen M., Borcherding J. (2012) Selective zooplanktivory of an invasive Ponto-Caspian mysid and possible consequences for the zooplankton community structure of invaded habitats. Aquatic Sciences, 74: 191-202

Fry B. (1983) Fish and shrimp migrations in the northern Gulf of Mexico analyzed using stable C, N and S isotope ratios. Fishery Bulletin, 81: 789-801

Gubelit Y.I., Berezina N.A. (2010) The causes and consequences of algal blooms: The Cladophora glomerata bloom and the Neva estuary (eastern Baltic Sea). Marine Pollution Bulletin, 61 (4): 183-188

Herkul K., Kotta J., Kotta I. (2006) Distribution and population characteristics of the alien talitrid amphipod Orchestia cavimana in relation to environmental conditions in the Northeastern Baltic Sea. Helgoland Marine Research, 60: 121-126

Herkul K., Kotta J., Puss T., Ilmar Kotta I. (2009) Crustacean invasions in the Estonian coastal sea. Estonian Journal of Ecology, 58 (4): 313-323

Jennings S., Pinnegar J.K., Polunin N.V.C., Warr K.J. (2002) Linking size-based and trophic analyses of benthic community structure. Marine Ecology Progress Series, 22: 77-85

Kelly D.W., Dick J.T.A. (2005) Effects of environment and an introduced invertebrate species on the structure of benthic macroinvertebrate species at the catchment level. Archiv fur Hydrobiologie, 164: 69-88

Laine A.O., Andersin A.-B., Leinio S., Zuur A.F. (2007) Stratification-induced hypoxia as a structuring factor of macro zoobenthos in the open Gulf of Finland (Baltic Sea). Journal of Sea Research, 57: 65-77

Lesutiene J., Gasiunaite Z.R., Strikaityte R., Ziliene R. (2014) Trophic position and basal energy sources of the invasive prawn Palaemon elegans in the exposed littoral of the SE Baltic Sea. Aquatic Invasions, 9 (1): 37-45

$$
-425-
$$


Lesutiene J., Gorokhova E., Gasiunaite Z.R., Razinkovas R. (2007) Isotopic evidence for zooplankton as an important food source for the mysid Paramysis lacustris in the Curonian Lagoon, the South-Eastern Baltic Sea. Estuarine, Coastal and Shelf Science, 73: 73-80

MacNeil C., Dick J.T.A., Elwood R.W. (1997) The trophic ecology of freshwater Gammarus spp (Crustacea: Amphipoda): problems and perspectives concerning the functional feeding group concept. Biological Reviews, 72: 349-364

Maximov A.A. (2003) Changes of bottom macrofauna in the eastern Gulf of Finland in 19852002. Proceedings of the Estonian Academy of Sciences, Biology, Ecology, 52 (4): 378-393

Maximov A.A. (2011) Large scale invasion of Marenzelleria spp. (Polychaeta; Spionidae) in the Eastern Gulf of Finland, Baltic Sea. Russian Journal of Biological Invasions, 2 (1): 11-19

Maximov A.A. (2015) The long-term dynamics and current distribution of macrozoobenthos communities in the Eastern Gulf of Finland, Baltic Sea. Russian Journal of Marine Biology, 41 (4): 300-310

Panov V.E., Krylov P.I., Telesh I.V. (1999) The St. Petersburg harbour profile. Initial risk assessment of alien species in Nordic coastal waters. Gollasch S., Leppakoski E. (eds.) Copenhagen, Nord, p. $225-244$

Post D.M. (2002) Using stable isotopes to estimate trophic position: Models, methods, and assumptions. Ecology, 83: 703-718

Shiganova T. (2005) Changes in appendicularian Oikopleura dioica abundance caused by invasion of alien ctenophores in the Black Sea. Journal of the Marine Biological Association of the UK, 85: 477-494

Takhteev V.V., Berezina N.A., Sidorov D.A. (2015) Check-list of Amphipoda (Crustacea) from continental waters of Russia, with data on alien species. Arthropoda Selecta, 24 (3): 335-370

Wiklund A-K.E., Sundelin B. (2001) Impaired reproduction in the amphipods Monoporeia affinis and Pontporeia femorata as a result of moderate hypoxia and increased temperature. Marine Ecology Progress Series, 222: 131-141

Wilhelm F.M., Schindler D.W. (1999) Effects of Gammarus lacustris (Crustacea: Amphipoda) on plankton community structure in a alpine lake. Canadian Journal of Fisheries and Aquatic Sciences, 56: $1401-1408$ 